\title{
6: 151653623-151770023
}

National Cancer Institute

\section{Source}

National Cancer Institute. 6:151653623-151770023. NCI Thesaurus. Code C41674.

Physical location of AKAP12_Gene 